\title{
Erratum zu: Rechnungswesen, Controlling, Bankrechnen
}

\section{Erratum zu:}

W. Grundmann, R. Rathner, Rechnungswesen, Controlling, Bankrechnen, Prüfungstraining für Bankkaufleute, https://doi.org/10.1007/978-3-658-31330-2

Ein technischer Fehler im Produktionsablauf hat dazu geführt, dass das Buch zunächst mit 2021 als Copyright Jahr veröffentlicht wurde. Das Copyright Jahr ist 2020. Dies wurde nachträglich korrigiert. 